\title{
Helical Heart Gating Algorithm
}

GE 横河メディカルシステム・研究開発 沈 雲 (Yun Shen) 土谷総合病院・放 木村 文子 (Fumiko Kimura)

目的：第三世代のヘリカルCTによる心大血管の画像(Axial image, MPR, MIPおよび 3 D画像)では、心拍動の影響に よる画質低下が問題となる。さらに、電子ビーム方式である超高速 CT と比較して、第三世代CTの Time Resolution (Full Reconstruction: 0.75-1.0 Sec) は覀く、心疾患の診断は困難であることも多い。これらの問題を解決するために、 我々は心拍動の影響を抑える独自の Helical Heart Gating Algorithm を提案し、その有効性を検討した。

方法: 独自の Helical Heart Gating Algorithm は ECG 情報、 helical overlapping reconstruction、 helical interpolation、 deconvolution technique 等の組み合わせより構成される。本 Algorithm の構成並びにその処理 Flow は Fig.1 で示されて いる。本 Algorithm は三つの Step によって構成され、まず ECG 情報とともにヘリカルスキャンが行われ、次は時間 分解能の改善、Artifactの低減、4D Volume セットの作成等の処理を行い、最後に、得られた4D Volume セットの元に 3D Image の作成等を行う。尚、ヘリカルの対向View補間による実効的な時間分解能の改善（倍）並びにhelical overlapping reconstruction technique はこのAlgorithmのもっとも重要な部分であり、このAlgorithmの元である。使用し

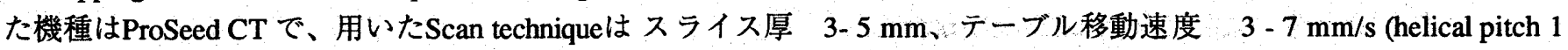
- 1.4)、 reconstruction pitch 0.1 、scan time 1 secである。

結果：ECG情報のない従来の画像と比較して、新しいHelical Heart Gating Algorithm を用いたAxial及び 3D 画像は、 㹡張期を選択することにより、心拍動の影響が著明に低減し、画質の改善が得られた(Fig.2)。本手法を用い、異時相、 同位置の画像を選択することにより横断面の動画を作成でき、さらに、異なる時相の 3D 画像を元にして、4D 画像 を得ることも可能であった。

結論：心拍動の影響を軽減する新しい Helical Heart Gating Algorithm を提案し、その有用性を確認した。

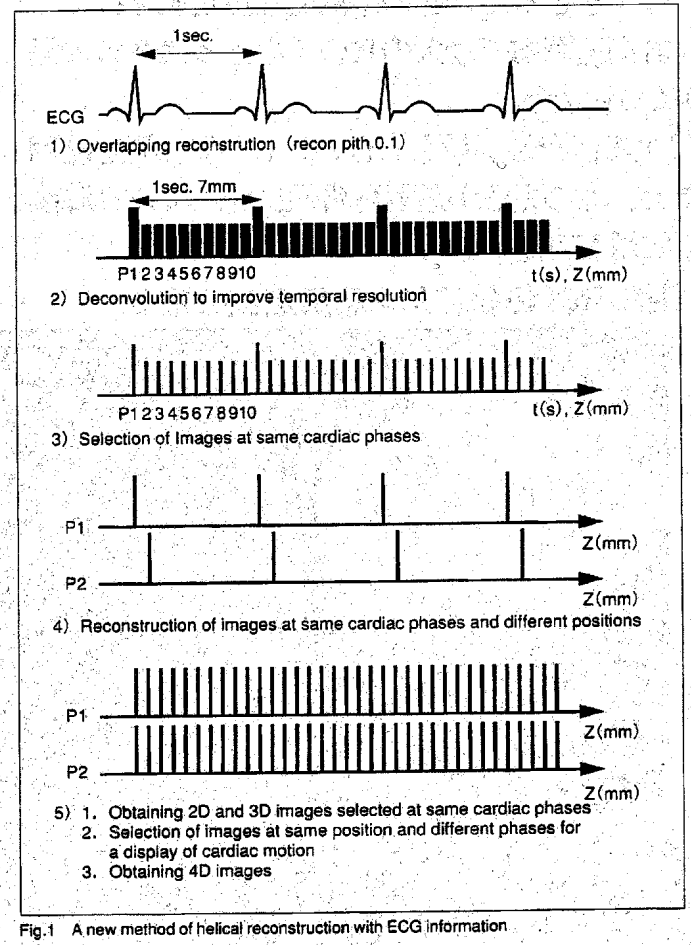

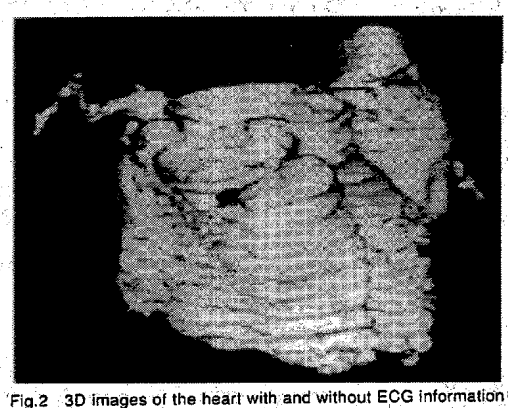

Fig. 30 images of the heart with and without ECG information (Heart rate $60 /$ min.)
A W Without ECG information artifacts due to cardiac motion are obvious.
$B:$ With ECG information and using selected images at the diastolic phase, motion artifacts are markedly reduced.

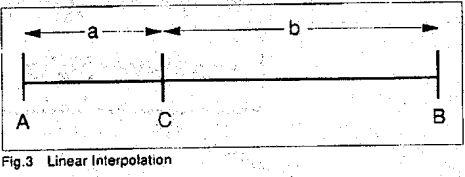

\section{付 绿}

1. Deconvolution 边理

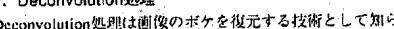

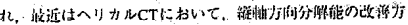

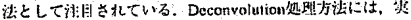

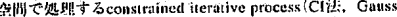

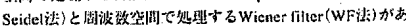

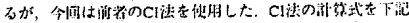
经过。

$X_{i}^{(R+1)}=X_{i}^{(R)}+\frac{d}{h_{i j}}\left(y_{i}-\sum_{j=i}^{i-1} h_{i j} X_{j}^{(R+1)}-\sum_{j=i}^{N} h_{i j} X_{j}^{(R)}\right)$

$x_{j}^{(k+1)}>0$

B; ileralion number, $y$; original image, $X$; dcblurring image
2. 䋺形相间

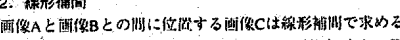

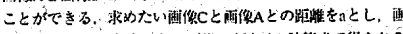

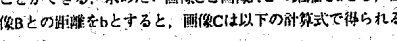
(Fig.3).

$C=\frac{b}{a+b} A+\frac{a}{a+b} B \quad \omega=\frac{b}{a+b}$
$=\omega A+(1-\omega) B$

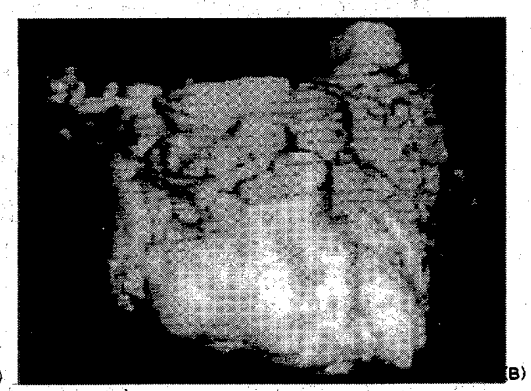

motion artifacts are markedly reduced. 